ИСПИТИВАҢЕ НИВОА ИНФОРМИСАНОСТИ О БОЛЕСТИ И НИВОА ЗАДОВОЉСТВА КВАЛИТЕТОМ ПРУЖЕНИХ УСЛУГА ЗДРАВСТВЕНЕ НЕГЕ, ЛЕЧЕЊЕМ И ЕДУКАЦИЈОМ БОЛЕСНИКА СА ИНФАРКТОМ МИОКАРДА

Љиљана Кулић ${ }^{1}$, Милица Вујовић ${ }^{2}$, Весна Крстовић Спремо ${ }^{3}$

\title{
EXAMINATION OF LEVEL OF AWARENESS ON DISEASE AND LEVEL OF SATISFACTION WITH THE QUALITY OF PROVIDED HEALTH CARE SERVICES, TREATMENT AND EDUCATION OF PATIENTS WITH MYOCARDIAL INFARCTION
}

Ljiljana Kulić, Milica Vujović, Vesna Krstović Spremo

\section{Сажсетак}

Увод. Кардиоваскуларне болести представљају водеће узроке оболеваға, одсуствована са посла, инвалидности и превремене смртности у свим земьама Европе. Овај тренд је нажалост исти широм света.

Циљ рада је испитивање нивоа информисаности о болести од стране здравствених радника и нивоа задовољства квалитетом пружених услуга здравствене неге, лечењем и едукачијом болесника са инфарктом миокарда.

Метод рада. Спроведено је ретроспективно-проспективно истраживање, дизајнирано као студија пресека. У истражсивању су коришћени: соииодемографски упитник, упитник за прочену здравственог стања, о животним навикама, коморбидитетима и карактеристикама тегоба оболелих, Short Form 36 Health Survey-SF-36 и упитник o информисаности и заинтересованости оболелих од АIM-а за стищањье знана о юиховој здравственој нези. Статистичка анализа података је урађена помоћу SPSS софтверског статистичког програма.

\section{Summary}

Introduction. Cardiovascular diseases are the leading causes of illness, absence from work, disability and premature mortality in all countries of Europe. This trend is unfortunately the same around the world.

Objective is to examine the level of awarenesson the disease by health workers and the level of satisfaction with the quality of the provided health care services, treatment and education of patients with myocardial infarction.

Methods. A retrospective-prospective study was conducted, designed as a cross-sectional study. The survey used the following: Sociodemographic questionnaire, Questionnaire for assessment of health status, life habits, comorbidities and characteristics of the illnesses of patients, Health Survey-SF-36 and Questionnaire on information and interest of AMI patients for acquiring knowledge about their health care. Statistical analysis of data was made using the SPSS statistical software.

Results. The study covered 175 respondents, $68 \%$ of respondents stated that it was fully informed by health professionals about their illness, 22,9\% were partially, while the remaining 9,1\% of respondents were not informed at all. A statistically significant difference in

\footnotetext{
${ }^{1}$ Доц. др Љиљана Кулић, Медицински факултет Универзитета у Приштини, Косовска Митровица, Cpбија (Ljiljana Kulić, PhD, Assistant Professor, University of Priština, Faculty of Medicine, Kosovska Mitrovica, Serbia).

${ }^{2}$ Мр Милица Вујовић, Одељење за неурохирургију, Клиничко болнички центар Подгорица, Црна Гора (Milica Vujović, MSc, Odeljenje za neurohirurgiju, KBC Podgorica, Montenegro).

${ }^{3}$ Проф. др Весна Крстовић Спремо, Медицински факултет Универзитета у Источном Сарајеву, Фоча, Република Српска (Vesna Кrstović Spremo, PhD, Professor, University of Istočno Sarajevo, Faculty of Medicine, Foča, Republic of Srpska).
} 
Резултати. Студијом је обухваћено 175 испитаника, 68\% испитаника је изјавило да је у потпуности информисано од стране здравствених радника о својој болести, 22,9\% је делимично, док преосталих 9,1\% испитаника није уопште информисано. Уочена је висока статистички значајна разлика у погледу информисаности болесника $\left(\chi^{2}=32,488 ; p=0,001\right)$, при чему је значајно већи број испитаника старије доби, који су делимично или потпуно информисани (55,1\%), у односу на млађу групу испитаника (36\%), а у односу на пол није уочена статистички значајна разлика. Квалитетом пружених услуга задовољно је 83,4\% испитаника, старији (50,9\%) су задовољнији од млађих (32,6\%), али разлика није статистички значајна. Између две групе испитаника различитог пола није уочена статистички значајна разлика $у$ односу на задовољство квалитетом пружених услуга у болници. Већина испитаника (89,7\%) сматра да медицинске сестре посвећују довољно пажње юиховој едукацији и лечењу, при чему између група испитаника у односу на старост и пол не постоји статистички значајна разлика.

Дискусија. Око две трећине је у потпуности, око једне петине делимично, а око једне десетине није уопште информисано о својој болести од стране здравствених радника. У односу на старост, уочена је висока статистички значајна разлика y погледу информисаности, при чему је значајно већи број старијих испитаника делимично или потпуно информисано, y односу на млађе, а у односу на пол није уочена статистички значајна разлика. Квалитетом пружених услуга задовољно је око 80\%, старији су задовољнији од млађих, али разлика није статистички значајна, а није уочена статистички значајна разлика у односу на пол. Око 90\% сматра да медицинске сестре посвећују довољно пажне юиховој едукачији и лечењу, а у односу на старост и пол не постоји статистички значајна разлика. patient information was observed $(\chi 2=32,488$; $p=0,001)$, with a significantly higher number of elderly respondents who were partially or fully informed $(55,1 \%)$ compared to the younger group of respondents (36\%), and statistically significant difference was noticed in relation to gender. The quality of the services provided is satisfied with $83,4 \%$ of the respondents, the elderly $(50,9 \%)$ are satisfied with the younger ones $(32,6 \%)$, but the difference is not statistically significant. There was no statistically significant difference between the two groups of respondents of different sexes in relation to satisfaction with the quality of services provided in the hospital. Most respondents (89,7\%) think that nurses pay enough attention to their education and treatment, where there is no statistically significant difference between the groups of respondents compared to age and gender.

Discussion. About two-thirds is fully, about one-fifth is partly and about one-tenth is not fully informed about their illness by health workers. Compared to age, there was a high statistically significant difference in terms of information, with significantly higher number of elderly respondents being partially or fully informed compared to younger ones, and statistically significant difference was noticed in relation to gender. The quality of services provided is satisfactory in about $80 \%$, the older are satisfied with the younger ones, but the difference is not statistically significant, and there is no statistically significant difference in relation to gender. Approximately 9\% of them think that nurses pay enough attention to their education and treatment, and there is no statistically significant difference in relation to age and gender.

Conclusion. Regarding the level of information about their illness by health workers, the majority of respondents, about two-thirds said that it is completely, about one-fifth, partly, and about one-tenth, that they are not informed at all about their illness by health workers. Compared to age, a statistically significant difference was observed in terms of information, 
Закључак. У погледу нивоа информисаности о својој болести од стране здравствених радника највећи број испитаника, око две трећине, изјавило је да је у потпуности, око једне петине делимично, а око једне десетине да није уопште информисано о својој болести од стране здравствених радника. У односу на старост уочена висока статистички значајна разлика у погледу информисаности, при чему је значајно већи број испитаника старије доби који су делимично или потпуно информисани, у односу на млађу групу испитаника, а у односу на пол није уочена статистички значајна разлика у погледу информисаности. Квалитетом пружених услуга у болници и посвећеном пажном ниховој едукацији и лечењу од стране медииинских сестара задовољна је већина болесника са инфарктом миокарда, али у односу на старост и пол не постоји статистички значајна разлика.

Кључне речи: инфаркт миокарда, информисаност, здравствена нега, лечење, едукаиија болесника. with a significantly higher number of respondents of the elderly who were partially or fully informed compared to the younger group of respondents, and statistically significant difference in terms of information was noticed in relation to gender. Most patients with myocardial infarction are satisfied with the quality of hospital care and attention given to their education and treatment by nurses, but there is no statistically significant difference in relation to age and gender.

Keywords: myocardial infarction, awareness, health care, treatment, patient education.

\section{УВОД}

$\mathrm{K}$ ардиоваскуларне болести представљају водеће узроке оболевања, одсуствовања са посла, инвалидности и превремене смртности у свим земљама Европе. Сваке године у свету од болести срца и крвних судова умире преко 17,3 милиона људи, а до 2030. године број умрлих износиће око 23 милиона. Светска федерација за срце упозорава да $82 \%$ смртних исхода од болести срца и крвих судова и више од $60 \%$ оптерећења исхемијском болешћу срца потиче из ниско и средње развијених земаља. То значи да у Србији сваког сата од различитих облика кардиоваскуларних болести умире шест особа. Као најтежи облик исхемијских болести срца, акутни коронарни синдром (АКС), који укључује акутни инфаркт миокарда и нестабилну ангину пекторис, водећи је здравствени проблем у развијеним земљама света, а последњих неколико деценија и у земљама у развоју. Болести срца и крвних судова су у Србији водећи узрок оболевања и умирања и код више од половине од укупног броја умрлих узрок смрти су болести срца и крвних судова. Морталитет од АКС у Србији износи 68,4 на 100.000 становника. Између 16.000 и 18.000 пацијената доживи инфаркт годишње, а да трећина њих никада не дође у болницу. $(1,2)$ За болеснике са инфарктом миокарда веома је значајна информисаност о болести од стране здравствених радника. Поред тога веома је значајно да ли су болесници задовољни квалитетом пружених услуга здравствене неге, едукацијом о њиховој болести и лечењем. 


\section{ЦИЉ РАДА}

Циљ овог рада је испитивање нивоа информисаности о болести од стране здравствених радника и нивоа задовољства квалитетом пружених услуга здравствене неге, лечењем и едукацијом болесника са инфарктом миокарда.

\section{МЕТОД РАДА}

У циљу испитивања нивоа информисаности о болести од стране здравствених радника, задовољства квалитетом пружених услуга здравствене неге и нивоа посвећивања медицинских сестара едукацији и лечењу болесника са инфарктом миокарда, спроведено је ретроспективнопроспективно истраживање, дизајнирано као студија пресека. Истраживање је спроведено у Интернистичкој амбуланти Клиничко-болничког центра у Подгорици и Дому здравља у Подгорици, при доласку пацијената на контролне прегледе. У истраживању су коришћени: социодемографски упитник, упитник за процену здравственог стања, о животним навикама, коморбидитетима и карактеристикама тегоба оболелих, Short Form 36 Health Survey-SF-36 и упитник о информисаности и заинтересованости оболелих од AIM-а за стицање знања о њиховој здравственој нези. Статистичка анализа података је урађена помоћу SPSS софтверског статистичког програма. Од непараметријских статистичких тестова су коришћени Ні-квадрат (тест, а од параметријских тестова је коришћен тест независних узорака. Разлика на нивоу вероватноће $\mathrm{p}<0,05$ се сматра статистички значајном, a вероватноћа $\mathrm{p}<0,01$ he се сматрати високо статистички значајном. Резултати ће бити приказани у виду табела.

\section{РЕЗУЛТАТИ}

Студијом је обухваћено 175 испитаника старости од 20 и више година, међу којима највећи број испитаника $(61,7 \%)$ припада старосној групи од 51 до 70 година, док преосталих $38,3 \%$ испитаника припада млађој старосној групи од 20 до 59 година, a просечна старост испитаника је 53,12 година. Међу испитаницима је било било 113 (64,6\%) мушкараца и 62 (35,4\%) жене.

У погледу нивоа информисаности о својој болести од стране здравствених радника, 68\% испитаника је изјавило да је у потпуности информисано од стране здравствених радника о својој болести, $22,9 \%$ је делимично, док преосталих 9,1\% испитаника није уопште информисано о својој болести. Између две старосне групе испитаника је уочена висока статистички значајна разлика у погледу информисаности $(\chi 2=32,488 ; p=0,001)$, при чему је значајно већи број испитаника старије доби који су делимично или потпуно информисани $(55,1 \%)$, у односу на млађу групу испитаника (36\%). Између две групе испитаника различитог пола није уочена статистички значајна разлика у погледу информисаности (Табела 1). 
Табела 1. Подаџи добијени анкетом о нивоу информисаности о својој болести од стране здравствених радника у односу на пол и старост испитаника.

\begin{tabular}{|c|c|c|c|c|c|c|}
\hline \multirow[t]{2}{*}{$\begin{array}{l}\text { Редни } \\
\text { број }\end{array}$} & \multirow[t]{2}{*}{$\begin{array}{c}\text { Социо-демографске } \\
\text { карактеристике испитаника }\end{array}$} & \multicolumn{3}{|c|}{$\begin{array}{c}\text { Да ли сте довољно информисани о својој } \\
\text { болести од стране здравствених радника? } \\
\text { Број (\%) }\end{array}$} & \multirow[t]{2}{*}{$\chi^{r}$} & \multirow[t]{2}{*}{$p$} \\
\hline & & Да & Делимично & $\mathrm{He}$ & & \\
\hline 0 & 1 & 2 & 3 & 4 & 5 & 6 \\
\hline 1 & $\begin{array}{l}\text { Старост } \\
20-50 \text { година } \\
51-70 \text { година }\end{array}$ & $\begin{array}{l}62(35,4) \\
57(32,6)\end{array}$ & $\begin{array}{c}1(0,9) \\
39(22,3)\end{array}$ & $\begin{array}{c}4(2,3) \\
12(6,9)\end{array}$ & 32,488 & 0,001 \\
\hline 2 & $\begin{array}{l}\text { Пол } \\
\text { Мушкарци } \\
\text { Жене }\end{array}$ & $\begin{array}{l}78(44,6) \\
30(17,1)\end{array}$ & $\begin{array}{c}26(14,9) \\
14(8)\end{array}$ & $\begin{array}{l}9(5,1) \\
7(4)\end{array}$ & 0,356 & 0,551 \\
\hline
\end{tabular}

Квалитетом пружених услуга задовољно је $83,4 \%$ испитаника. Испитаници старије доби $(50,9 \%)$ задовољнији су квалитетом пружених услуга у болници за разлику од млађе популације (32,6\%), међутим, разлика није статистички значајна. Када је у питању пол, између две групе испитаника различитог пола није уочена статистички значајна разлика у односу на задовољство квалитетом пружених услуга у болници (Табела 2).

Табела 2. Подаџи добијени анкетом о задовољству квалитетом пружених услуга у току боравка у болници у односу на пол и старост испитаника.

\begin{tabular}{|c|c|c|c|c|c|}
\hline \multirow[t]{2}{*}{$\begin{array}{l}\text { Редни } \\
\text { број }\end{array}$} & \multirow[t]{2}{*}{$\begin{array}{c}\text { Социо-демографске } \\
\text { карактеристике испитаника }\end{array}$} & \multicolumn{2}{|c|}{$\begin{array}{c}\text { Да ли сте задовољни квалитетом } \\
\text { пружених услуга у болници? } \\
\text { Број (\%) }\end{array}$} & \multirow[t]{2}{*}{$\chi^{Y}$} & \multirow[t]{2}{*}{$p$} \\
\hline & & Да & $\mathrm{He}$ & & \\
\hline 0 & 1 & 2 & 3 & 4 & 5 \\
\hline 1 & $\begin{array}{l}\text { Старост } \\
20-50 \text { година } \\
51-70 \text { година }\end{array}$ & $\begin{array}{l}57(32,6) \\
89(50,9)\end{array}$ & $\begin{array}{c}10(5,7) \\
19(10,9)\end{array}$ & 0,213 & 0,645 \\
\hline 2 & $\begin{array}{l}\text { Пол } \\
\text { Мушкарци } \\
\text { Жене }\end{array}$ & $\begin{array}{l}96(54,9) \\
50(28,6)\end{array}$ & $\begin{array}{l}17(9,7) \\
12(6,9)\end{array}$ & 0,538 & 0,463 \\
\hline
\end{tabular}

Већина испитаника $(89,7 \%)$ сматра да медицинске сестре посвећују довољно пажње њиховој едукацији и лечењу, при чему између група испитаника у односу на старост и пол не постоји статистички значајна разлика (Табела 3 ). 
Табела 3. Став испитаника о нивоу посвећивања медицинских сестара едукаџији и лечењу испитаника у односу на пол и старост испитаника.

\begin{tabular}{|c|c|c|c|c|c|}
\hline \multirow[t]{2}{*}{$\begin{array}{l}\text { Редни } \\
\text { број }\end{array}$} & \multirow[t]{2}{*}{$\begin{array}{c}\text { Социо-демографске } \\
\text { карактеристике испитаника }\end{array}$} & \multicolumn{2}{|c|}{$\begin{array}{c}\text { Сматрате ли да медицинска сестра } \\
\text { посвећује довољно пажње Вашој } \\
\text { едукацији и лечењу? } \\
\text { Број (\%) }\end{array}$} & \multirow[t]{2}{*}{$\chi^{r}$} & \multirow[t]{2}{*}{$p$} \\
\hline & & Да & $\mathrm{He}$ & & \\
\hline 0 & 1 & 2 & 3 & 4 & 5 \\
\hline 1 & $\begin{array}{l}\text { Старост } \\
20-50 \text { година } \\
51-70 \text { година }\end{array}$ & $\begin{array}{l}62(35,4) \\
95(54,3)\end{array}$ & $\begin{array}{c}5(2,9) \\
13(7,4)\end{array}$ & 0,938 & 0,333 \\
\hline 2 & $\begin{array}{l}\text { Пол } \\
\text { Мушкарци } \\
\text { Жене }\end{array}$ & $\begin{array}{c}102(58,3) \\
55(31,4)\end{array}$ & $\begin{array}{c}11(6,3) \\
7(4)\end{array}$ & 0,105 & 0,746 \\
\hline
\end{tabular}

\section{ДИСКУСИЈА}

У погледу нивоа информисаности о својој болести од стране здравствених радника највећи број испитаника, око две трећине, изјавило је да је у потпуности, око једне петине делимично, а око једне десетине да није уопште информисано о својој болести од стране здравствених радника. У односу на узраст, односно старост уочена је висока статистички значајна разлика у погледу информисаности $(\chi 2=32,488 ; \quad \mathrm{p}=0,001)$, при чему је значајно већи број испитаника старије доби који су делимично или потпуно информисани (више од половине), у односу на млађу групу испитаника (трећина). Између две групе испитаника различитог пола није уочена статистички значајна разлика у погледу информисаности. Квалитетом пружених услуга задовољна је већина испитаника, њих око 80\%, при чему су испитаници старије доби задовољнији квалитетом пружених услуга у болници за разлику од млађе популације, али разлика није статистички значајна. Када је у питању пол, није уочена статистички значајна разлика у односу на задовољство квалитетом пружених услуга у болници. Већина испитаника (око 90\%) сматра да медицинске сестре посвећују довољно пажње њиховој едукацији и лечењу, при чему између група испитаника у односу на старост и пол не постоји статистички значајна разлика. Резултати овог истраживања потврђују резултате из литературе. ${ }^{(3-9)}$

\section{ЗАКЉУЧАК}

У погледу нивоа информисаности о својој болести од стране здравствених радника највећи број испитаника, око две трећине, изјавило је да је у потпуности, око једне петине делимично, а око једне десетине да није уопште информисано о својој болести од стране здравствених радника. У односу на старост уочена је висока статистички значајнаразликау погледу информисаности, при чему је значајно већи број испитаника старије доби који су делимично или потпуно информисани, у односу на млађу групу испитаника, а у односу на пол није уочена статистички значајна разлика у погледу информисаности. Квалитетом пружених услуга у болници и посвећеном пажњом њиховој едукацији и лечењу од стране медицинских сестара задовољна је већина болесника са инфарктом миокарда, али у односу на старост и пол не постоји статистички значајна разлика. 


\section{ЛИТЕРАТУРА}

1. Министарство здравља Републике Србије и Институт за јавно здравље Србије „Др Милан Јовановић Батут“. Финални извештај и Основни резултати истраживања здравља становника Републике Србије у 2015. години, Здравствено статистички годишњак за 2015. годину. http://www.batut.org.rs/ index.php? content $=59$.

2. Asadi-Lari M, Tamburini M, Gray D. Patients needs, satisfaction and health related quality of life: Towards a comprehensive model. Health and Quality of Life Outcome, 2004; 2: 32.

3. Rančić N., Petrović B., Apostolović S., Mandić M., Antić I. Assessment of healthrelated quality of life in patients after acute myocardial infarction. Med Pregl, 2011; LXIV(9-10): 453-460.

4. Kristofferzon LM, Lofmark R., Carlsson M. Perceived coping, social support, and quality of life 1 month after myocardial infarction: a comparison between Swedish women and men. Heart Lung, 2005; 34(1): 39-50.

5. Васиљевић 3., Матић Д., МицковскиКаталина Н., Панић Г., Кротин М., Путниковић Б., и сар. Клиничка обележја, лечење и смртност болесника с акутним коронарним синдромом у

Србији од 2002 до 2005. године: анализа података националног регистра за акутни коронарни синдром. Srp Arh Celok Lek, 2007; 135(11-12): 645-54.

6. Dobrić M., Ostojić M., Nedeljković M., Vukčević V., Stanković G., Stojković S., et al. Treatment of acute ST elevation myocardial infarction with primary percutaneus coronary intervention in Department of cardiology, Clinical centre of Serbia, Belgrade: movement and treatment of patients from the onset of chest pain till the attempt of reopening the infarct-related artery. Srp Arh Celok Lek, 2007; 135(9-10): 521-31.

7. Secondary prevention after a myocardial infarction. NICE quality standard 99. Issued: September 2015. Доступно на: http://www.nice.org.uk/guidance/qs99. Датум приступа: 28. 6. 2016.

8. Вуковић Глорија Гочин. Здравствена њега у кардиологији, умијеће садашњости и изазов будућности. Cardiologia Croatica, 9 (2014).

9. Мијаиловић 3М, Стајић 3., Јевтић М., Александрић С., Матуновић Р., Тавчиовски Д. Терапијски приступ код пацијената који се подвргавају перкутаним коронарним интервенцијама. Мед. прегл, 2009; 62(7-8): 331-6.

Контакт: Доц. др Љиљана Кулић, Универзитет у Приштини, Медицински факултет, Косовска Митровица. 